\title{
Nutrient recycling by coastal sediments: effects of added algal material
}

\author{
V. Enoksson \\ Department of General and Marine Microbiology, University of Göteborg, Carl Skottsbergs Gata 22, \\ S-41319 Göteborg, Sweden
}

\begin{abstract}
The deposition of a Skeletonema bloom onto sediment collected in a coastal bay was simulated and the effects on $\mathrm{O}_{2}, \mathrm{~N}$ and $\mathrm{P}$ fluxes were recorded. A comparison of calculated net production and observed net efflux of inorganic nitrogen ( $\mathrm{IN}=$ ammonium + nitrate) for the period prior to the addition of algae, indicated that two-thirds of the produced ammonium was nitrified and subsequently denitrified. Algal additions induced a dramatic and persistent rise in oxygen consumption $(1.6 \times)$ and release of IN $(4.5 \times)$. DON (dissolved organic nitrogen, $2 x$ ), and $\mathrm{PO}_{4}{ }^{3-}(3 \times)$. Of the added algal $\mathrm{N}$ ( $76 \mathrm{mmol} \mathrm{N} \mathrm{m}{ }^{-2}$ ), $33 \%$ was recycled as $\mathrm{NH}_{4}{ }^{+}$and DON during the $19 \mathrm{~d}$ of incubation and, according to $\mathrm{PO}_{4}{ }^{3-}$ measurements, the same was true for the algal $\mathrm{P}$, giving a half-life of the algal biomass of ca $4 \mathrm{wk}$. Comparison of calculated net production and observed net efflux of IN indicated a considerably decreased denitrification/mineralisation ratio due to algal additions. Extrapolating to the size of Laholm Bay, SE Kattegat (sampling site), suggests that the settlement of algae (realistic amount used here) would make the sediment the most important nutrient source of this bay for a few weeks period. DON was a significant part of the released, non-gaseous nitrogen, both before $(46 \%)$ and after $(27 \%)$ the addition of algae. In cores subjected to anaerobic conditions, the concentrations of DON decreased considerably, suggesting that the production of DON was inhibited during such conditions and that much of the DON in this sediment was easily utilized
\end{abstract}

\section{INTRODUCTION}

Many coastal areas receive increasing loads of landbased fertilizers (Meybeck 1982) which are incorporated into the planktonic biota and eventually exported to deeper layers through sedimentation of particulate organic material (Dugdale \& Goering 1967 , Eppley et al. 1983, Wassmann 1990). In coastal, relatively shallow areas, much of the particulate material reaches the sediment where it is decomposed at the expense of oxygen. The sediments therefore react upon the increased deposition of organic material by increasing both the oxygen demand and the recycling of nutrients to the water (Boynton et al. 1980, Nixon 1981, Kelly \& Nixon 1984). Garber (1984a) as well as Kelly \& Nixon (1984) demonstrated that additions of phytoplankton to the sediment surface resulted in a rapid release of ammonium from the sediment.

Denitrifying bacteria are able to reduce nitrate to nitrogen gas if supplied with organic substrate during suboxic or anoxic conditions. Coastal sediments provide both organic substrate and anoxic conditions and thus, nitrate that enters the anoxic or suboxic zones of the sediment will be denitrified. It appears that nitrate, and therefore nitrification is the crucial regulatory factor for denitrification in coastal sediments (Koike \& Sørensen 1988). The strictly aerobic nitrifying bacteria may either be stimulated or inhibited by the increased organic input depending on which effect is the most crucial: the increased availability of ammonium or the decreased availability of oxygen (Henriksen \& Kemp 1988). Jenkins \& Kemp (1984) stressed the importance of a close coupling between nitrification and denitrification in the sediment for the efficient removal of combined nitrogen from biological production. Many nitrogen budgets over entire coastal areas as well as mass balance calculations based on sediment water flux studies, arrive at a loss term which is assumed to be partially due to denitrification (Balzer 1984, Shaffer \& Rönner 1984, Boynton \& Kemp 1985, Enoksson \& 
Table 1. Protocol for sediment sampling; analyses and incubation (sediment-water flux measurements) of sub-cores trom box-core samples $(30 \times 30 \mathrm{~cm})$ taken from $22 \mathrm{~m}$ depth in Laholm Bay, western Sweden, in September 1984

\begin{tabular}{|c|c|c|c|c|c|}
\hline Use & Parameters & $\begin{array}{l}\text { No. of } \\
\text { cores }\end{array}$ & $\begin{array}{l}\text { Core } \\
\text { diameter } \\
(\mathrm{cm})\end{array}$ & $\begin{array}{l}\text { Seg. } \\
\text { ments } \\
(\mathrm{cm})\end{array}$ & Manipulation \\
\hline Analyses & Porosity, org. C, tot. N & 2 & 5 & $1-3$ & - \\
\hline Analyses & Redox potential (Eh) & 5 & 5 & 1 & - \\
\hline Analyses & Pore-water $\mathrm{N}, \mathrm{K}^{+}$-exchangeable $\mathrm{NH}_{4}{ }^{+}$ & 3 & 8 & $1-3$ & - \\
\hline $\begin{array}{l}\text { Incubation; } \\
\text { followed by core } \\
\text { analyses }\end{array}$ & $\begin{array}{l}\text { Flux of } \mathrm{O}_{2} \text {, nutrients and DON } \\
\text { Porosity, pore-water } \mathrm{N}_{1} \mathrm{~K}^{+} \text {-exchangeable } \\
\mathrm{NH}_{4}{ }^{+} \text {, org. } \mathrm{C} \text {, tot. } \mathrm{N}\end{array}$ & 4 & 8 & $0.5-3$ & $\begin{array}{l}\text { No addition of algae; water } \\
\text { flow stopped above } 1 \text { core } \\
\text { on Day } 30\end{array}$ \\
\hline $\begin{array}{l}\text { Incubation; } \\
\text { followed by core } \\
\text { analyses }\end{array}$ & $\begin{array}{l}\text { Flux of } \mathrm{O}_{2} \text {, nutrients and } \mathrm{DON} \\
\text { Porosity, pore-water } \mathrm{N}_{1} \mathrm{~K}^{+} \text {-exchangeable } \\
\mathrm{NH}_{4}^{+} \text {, org. } \mathrm{C} \text {, tot. } \mathrm{N}\end{array}$ & 4 & 8 & $0.5-3$ & $\begin{array}{l}\text { Algae added on Day } 10 \\
\text { water flow stopped above } 1 \\
\text { core on Day } 30\end{array}$ \\
\hline
\end{tabular}

Samuelsson 1987, Enoksson et al. 1990, Wulff et al. 1990). These studies, as well as direct measurements of denitrification (Seitzinger et al. 1984, Jensen et al. 1988, Kemp et al. 1990, Kieskamp et al. 1991) show that substantial amounts of nitrogen are denitrified in the sediment, often around $50 \%$ of the nitrogen input to the area (Seitzinger 1988). Even though benthic nitrification was often the main source of nitrate for denitrification in many well-mixed areas (Seitzinger 1988), deep water nitrate appeared to be more important during periods with high nitrate concentrations in deep water and/or with input of labile organic material in the stratified Aarhus Bight, Denmark (Jensen et al. 1988, 1990). In Chesapeake Bay (USA), the denitrification was dependent on nitrification and both processes therefore stopped in the summer when oxygen availability in the sediment was insufficient, resulting in large amounts of ammonium being recycled to the deep water (Kemp et al. 1990).

Laholm Bay is situated on the Swedish west coast and is open to the Kattegat. The productive layers are separated from deep water by a sharp halocline at a mean depth of $15 \mathrm{~m}$ due to the flow of brackish water from the Baltic Sea (Svanson 1975). Suboxic deep water has become a problem in the autumn, not only in the bay but in recent years also over large areas in the Kattegat (Rosenberg et al. 1990). It is not yet clear if this is caused mainly by the large increase in the landbased supply of nitrate to Laholm Bay or to large-scale nutrient inputs (Rosenberg et al. 1990, Rydberg et al. 1990). Granéli et al. (1986) showed that in spite of large nitrogen inputs, the phytoplankton growth was stimulated when nitrate, but rarely when phosphate, was added to Laholm Bay water. Nearly half of the annual primary production of $144 \mathrm{~g} \mathrm{C} \mathrm{m}^{-2}$ is formed during the blooms in spring $(13 \%)$ and autumn (30\%) (Rydberg et al. 1990).

The aim of this study was to deduce whether or not the sediment of Laholm Bay may act as an important nutrient trap upon deposition of easily utilized organic material. The effects of algai additions onto the sediment were studied experimentally by the use of natural sediment samples incubated in a continuous-flow system in the laboratory. The release of nutrients and DON and the consumplion of oxygen by the sediments was monitored before and after the addition of algal material.

\section{MATERIALS AND METHODS}

Materials. Sediment samples were taken in Laholm Bay, Sweden, at a depth of $22 \mathrm{~m}$ (Stn YG, 56 $33.5^{\prime} \mathrm{N}$, $12^{\circ} 34.2^{\prime} \mathrm{E}$ ) on 19 September 1984 . The autumn bloom had not reached its maximum and the deep water was oxygenated. The deep water was sampled with a $30 \mathrm{l}$ Niskin sampler. Undisturbed sediment was obtained using a box-core sampler $(30 \times 30 \mathrm{~cm})$ and subsamples were taken with acrylic plexiglass tubes for sediment analyses and incubation as listed in Table 1 . Some cores were processed without delay, both with respect to pore-water and whole sediment constituents (Table 1). Incubated cores were eventually subjected to the same measurements with the exception of redox potential. The macro-fauna were collected onto a $1 \mathrm{~mm}$ mesh sieve, initially from 1 box-core and at the end of the experiments from all incubated cores. The macro-fauna were dominated by Diastylis spp. (Crustacea), Ophiura albida and Amphiura filiformis (Echinodermata).

Methods for nitrogen fractions (nitrate, ammonium and total dissolved nitrogen (DN) \} are given below. $\mathrm{K}^{+}$exchangeable ammonium was obtained from 1:1 suspensions of sediment and $0.5 \mathrm{M} \mathrm{KCl}$ and porosity from $20 \mathrm{ml}$ portions of sediment that were dried at 90 and $105^{\circ} \mathrm{C}$. These samples were subsequently homoge- 
nized and 15 to $20 \mathrm{mg}$ portions were used for analyses of total $\mathrm{N}$ and $\mathrm{C}$ (Carlo Erba 1106 CHN analyser). Organic $C$ was derived from total $C$ by subtracting the carbonate-C fraction which was determined separately on 0.5 to $0.9 \mathrm{~g}$ portions of the samples. These samples were boiled for $30 \mathrm{~min}$ in gas-tight serum bottles with $4 \mathrm{ml}$ of $0.09 \%(\mathrm{v} / \mathrm{v})$ of concentrated $\mathrm{H}_{2} \mathrm{SO}_{4}$, supplied with $0.15 \% \mathrm{FeSO}_{4} \cdot 7 \mathrm{H}_{2} \mathrm{O}$, and blank bottles were prepared in the same way. The evolved $\mathrm{CO}_{2}$ (ca $20 \%$ of total C), was analysed with a coulometer (UIC Inc., Joliet, IL, USA). Redox potential (Eh) was determined as described by Enoksson \& Samuelsson (1987).

Flux measurements. Eight undisturbed cores, with the fauna intact, were used for sediment-water flux measurements (Table 1). They were incubated in darkness in a water bath at $10^{\circ} \mathrm{C}$ (in situ temperature) and the overlying water was connected to a flow-through (Fig. 1) by means of a peristaltic pump. The overlying water $(400$ to $550 \mathrm{ml}$ ) was gently stirred with a magnetic bar (50 rpm) and continuously 'diluted' with aerated deep water which was supplied from tanks that were kept in the same water bath as the cores (Fig. 1). Outflowing water from the sediment tubes was discarded. Analyses were made both on the overlying water which was sampled through the lid and on the inflowing deep water which was sampled from the supply tanks. The water samples were filtered (GF/F; Whatman glass fiber filters) and analysed within a

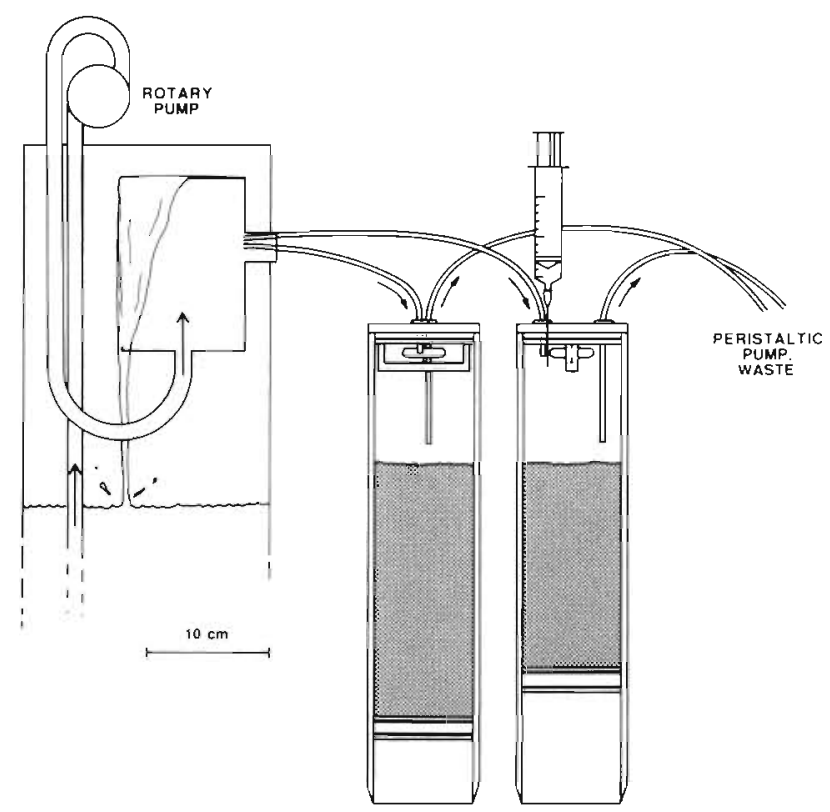

Fig. 1 The continuous flow system showing 1 of 2 supply tanks with deep water that is pumped to an internal beaker with overflow, and 2 of 8 incubation tubes with sediment and overlying water, the latter connected to flow-through of deep water, via gas-tight tubes, by means of a peristaltic pump. Incubation tubes are pictured from different angles. Silicon rubber was used for all ' $O$ '-rings and septa for sample withdrawal through the lids couple of hours. DN, from which the inorganic nitrogen was subtracted to give the dissolved organic nitrogen (DON), was analysed as nitrate after oxidation with persulphate in buffered solution (Valderrama 1981) and UV-light according to Enoksson \& Samuelsson (1987). Ammonium-N and $\alpha_{1} \alpha$-dipyridyl-N were recovered to $100 \%$ and urea-N to $80 \%$ by this method. Nitrate and nitrite were measured using a Technicon Autoanalyzer I (Armstrong et al. 1967), ammonium with the indophenol blue method (Koroleff 1976) and phosphate with the 2-reagent version of Murphy \& Riley (1962). Oxygen was analysed with a Clark-type electrode (Hansatech Ltd., King's Lynn, UK) using 5 or $10 \mathrm{ml}$ subsamples. The results were corrected for a slight oxygen diffusion through the plexiglass. In the following it is implied that sediment-water fluxes refer to net fluxes as calculated from the differences in concentration between inflowing water and overlying water. The calculations were made according to Sundbäck et al. (1991). Flux out of the sediment is referred to as positive flux. Flux data are presented as the mean of the parallel cores.

Skeletonema costatum was grown axenically to well beyond the stationary phase, harvested by centrifugation, and resuspended in deep water. No attempt was made to kill the algae. The suspension was added on Day 10 , to the water phase of 4 cores, the remaining 4 cores serving as controls (Table 1). The molar $\mathrm{C} / \mathrm{N}$ ratio of the algae was 6.4 and the additions corresponded to $480 \mathrm{mmol} \mathrm{C} \mathrm{m}^{-2}$ and $76 \mathrm{mmol} \mathrm{N} \mathrm{m}^{-2}$. Two cores, one with and one without added diatoms, were subjected to anoxic conditions by turning off the flowthrough of deep water on Day 30.

\section{RESULTS}

\section{In situ sediment characteristics}

The Eh was positive in the upper 1 to $2 \mathrm{~cm}$ of the sediment and the Eh discontinuity layer extended to a depth of $3 \mathrm{~cm}$. The sediment consisted of muddy sand with a solid fraction of ca $1 \mathrm{~g} \mathrm{~cm}^{-3}$ and a porosity of ca $60 \%$. The organic $\mathrm{C} / \mathrm{N}$ ratio was 10.2 in the upper $1 \mathrm{~cm}$ with an organic $\mathrm{C}$ content of $483 \mu \mathrm{mol} \mathrm{g}^{-1}$ dry wt ( $0.6 \%$ of dry wt) (Table 2$)$ The pore-water nitrate concentrations peaked in the upper $1 \mathrm{~cm}$ (cf. Table 2), and in 1 core the concentration exceeded the pore-water ammonium. Only traces of nitrate were found below $3 \mathrm{~cm}$ depth whereas ammonium concentrations increased uniformly downwards to about $5 \mathrm{~cm}$, below which depth there was no further increase (not shown). The pore-water and the $\mathrm{K}^{+}$-exchangeable pools of ammonium were of comparable size. 
Table 2. Organic carbon, total nitrogen, atomic $\mathrm{C} / \mathrm{N}$ ratio, gradients of nitrate and ammonium in the upper layer of sediment, in situ and after incubation (see Table 1 and text). Mean values are shown for the 3 parallels which were covered with oxic water at the end of the experiment (only 2 for org. $C$ and tot. $N$ in situ) with $S D$ given in parenthesis. $d C=\left(C_{p}-C_{w}\right)$, where $C_{p}=$ the porewater concentration at $0.25 \mathrm{~cm}$, and $C_{w}=$ the concentration in the overlying water. Analyses on $1 \mathrm{~cm}$ sections in situ and on $0.5 \mathrm{~cm}$ sections for incubated cores

\begin{tabular}{|c|c|c|c|c|c|}
\hline \multirow{2}{*}{$\begin{array}{l}\text { Sample } \\
\text { 'In situ' }\end{array}$} & \multicolumn{2}{|c|}{ 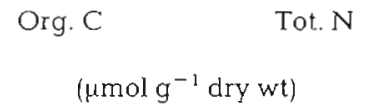 } & \multirow{2}{*}{$\begin{array}{c}\mathrm{C} / \mathrm{N} \\
10.2\end{array}$} & \multicolumn{2}{|c|}{${ }_{\left(\mu \mathrm{M} 0.25 \mathrm{~cm}^{-1}\right)^{\mathrm{NH}_{4}+}}^{\mathrm{d} C}$} \\
\hline & 483 & 48 & & $10(8)$ & $10(4)$ \\
\hline $\begin{array}{l}\text { Controls } \\
\text { Algae }\end{array}$ & $\begin{array}{l}323(28) \\
295(67)\end{array}$ & $\begin{array}{l}30(4) \\
27(7)\end{array}$ & $\begin{array}{l}10.9(0.7) \\
10.9(0.5)\end{array}$ & $\begin{array}{l}40(9) \\
40(14)\end{array}$ & $\begin{array}{l}48(18) \\
67(3)\end{array}$ \\
\hline
\end{tabular}
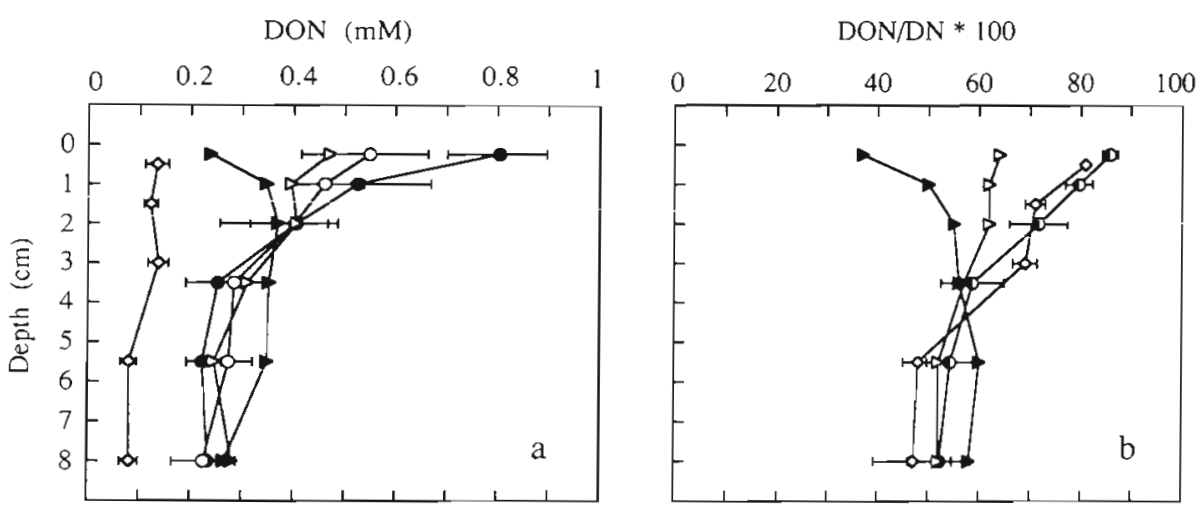

Fig. 2. (a) Depth distributions in the pore-water of dissolved organic nitrogen, $D_{0 N}(6)$ mean of 2 cores analysed upon collection; $(\bullet) 3$ cores incubated with oxygen and with added algae; $(0) 3$ cores with oxygen, without algae; $(\bullet) 1$ core without oxygen, with algae; ( $) 1$ core without oxygen and without algae (cf. Table 1). Horizontal bars indicate range. (b) DON as the percentage of total dissolved nitrogen, DON/DN $\times 100 ;(0)$ all 6 cores incubated with oxygen; other symbols as in (a). Horizontal bars indicate standard deviation

\section{Characteristics of incubated sediment cores}

A total number of 18 ophiuroids were evenly distributed between the manipulated cores and the controls. One or two polychaetes were also found in each core. The additions of diatoms caused an increase (not statistically significant, cf. Table 2) in the pore-water concentrations of ammonium in the cores that were cov- ered with oxic water until analysed (3 with algae and 3 controls). The $\mathrm{K}^{+}$-exchangeable ammonium constituted slightly less than one-third of the total ammonium pool in all incubated cores. The diatoms may have caused an accumulation of DON in the porewater (Fig. 2a), but the fraction of the pore-water nitrogen that was found in the DON pool was about the same in all the 'oxic' cores, and on average as high as

Table 3. Benthic oxygen consumption, sediment-water flux rates of phosphate, dissolved organic nitrogen (DON), inorganic nitrogen (IN, including nitrate flux if $>0$ ) and nitrate (if $<0$ ), presumed loss of IN (see text) and ratios between oxygen consumption and IN release and between IN release and phosphate release, presented as mean values for the periods before and after the addition of algal material to the sediment surface. Data represent 8 cores before Day 10 on which day algal material was added to 4 of the cores and 4 cores were used as controls (see Table 1)

\begin{tabular}{|c|c|c|c|c|c|c|c|c|c|c|}
\hline Day & Cores & $-\mathrm{O}_{2}$ & $\begin{array}{c}\mathrm{PO}_{4}^{3-} \\
\text { net }\end{array}$ & $\begin{array}{c}\text { DON } \\
\text { net } \\
\left(\mu \mathrm{mol} \mathrm{m}^{-2} \mathrm{~h}^{-1}\right)\end{array}$ & $\begin{array}{c}\text { IN } \\
\text { flux }>0\end{array}$ & $\begin{array}{l}\mathrm{NO}_{3}{ }^{-} \\
\text {flux }<0\end{array}$ & & $\begin{array}{l}\text { s' } \\
(\%)\end{array}$ & $-\mathrm{O}_{2} / \mathrm{IN}$ & $\mathrm{IN} / \mathrm{PO}_{4}{ }^{3-}$ \\
\hline $0-10$ & All & 332 & 1.09 & 8.5 & 10 & - & 23 & 69 & 33 & 9 \\
\hline $10-29$ & Controls & 301 & 0.10 & 5.1 & 7 & - & 20 & 74 & 42 & 70 \\
\hline $10-29$ & Algae & 540 & 3.61 & 17.9 & 49 & -4.4 & 16 & 25 & 11 & 14 \\
\hline
\end{tabular}



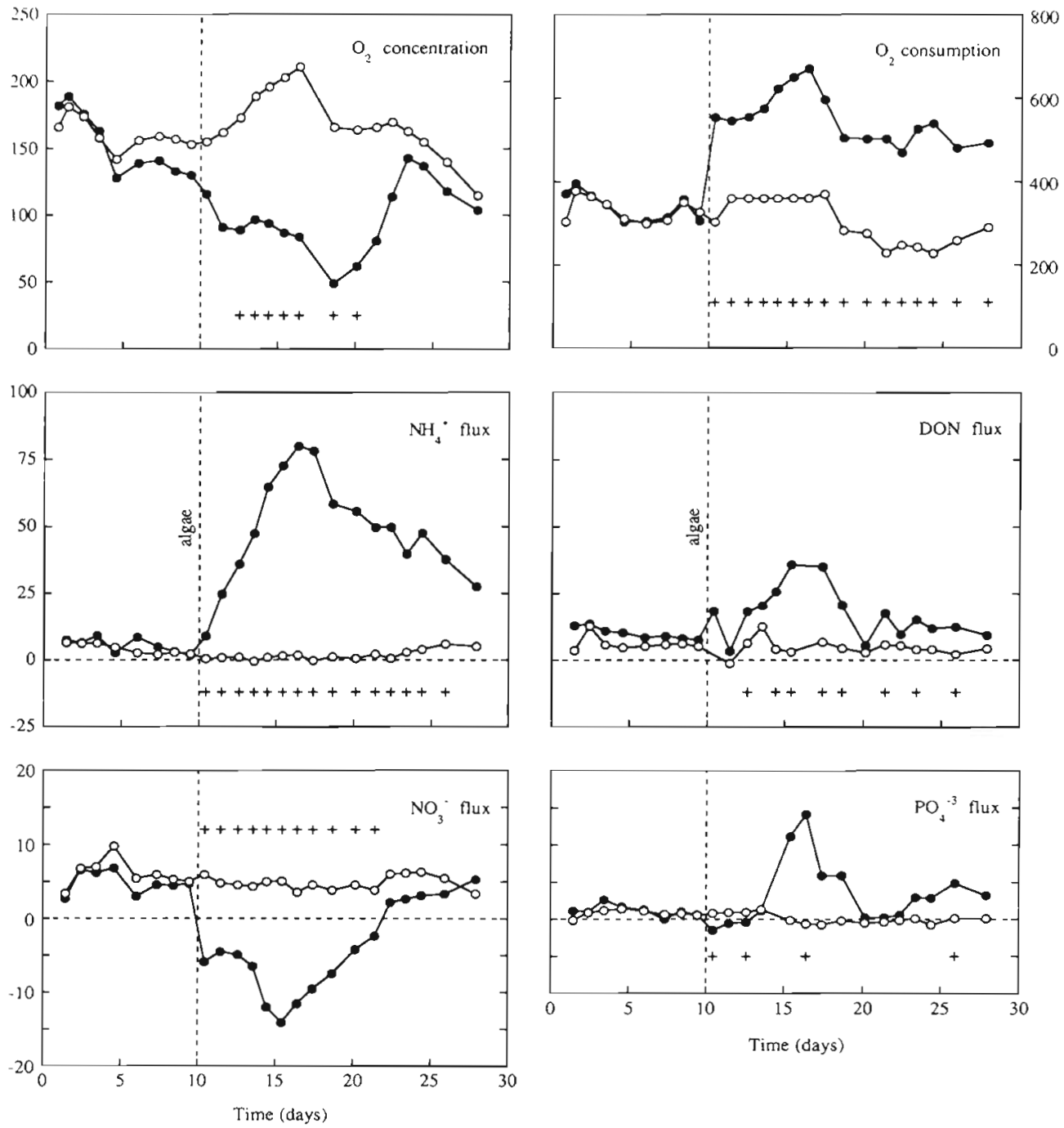

Fig. 3. Concentrations of oxygen $(\mu \mathrm{M}$ ), oxygen consumption and sediment-water exchange of ammonium, DON (dissolved organic nitrogen), nitrate and phosphate $\left(\mu \mathrm{mol} \mathrm{m} \mathrm{m}^{-2} \mathrm{~h}^{-1}\right)$ at various times for sandy sediment sampled in September (Table 1). Results represent the mean values from 4 cores without additions (O) and 4 cores with additions of algae on Day 10 ( $\bullet$ ). Fluxes out of the sediment are given positive values. (+) indicates significant (ANOVA, $p<0.05$ ) differences in flux rates between cores with and without algae

$86 \%$ in the upper $0.5 \mathrm{~cm}$ (Fig. $2 \mathrm{~b}$ ). This resembled the in situ situation but in the 2 cores that were finally incubated anoxically, the DON pool made up much less of the total pore-water nitrogen (Fig. 2b). The organic carbon and total nitrogen content of the sediment was not significantly different in the cores with and without added algae (Table 2).

\section{Flux rates without algal additions}

The benthic oxygen consumption rate obtained during the initial $10 \mathrm{~d}$ of incubation was low, around 330 $\mu \mathrm{mol} \mathrm{m}{ }^{-2} \mathrm{~h}^{-1}$, and decreased further during the subsequent $19 \mathrm{~d}$ of incubation (Fig. 3, Table 3). Rates of ammonium and nitrate release were both on average $5 \mu \mathrm{mol} \mathrm{m} \mathrm{m}^{-2} \mathrm{~h}^{-1}$ and the phosphate release on average $1.1 \mu \mathrm{mol} \mathrm{m} \mathrm{m}^{-2} \mathrm{~h}^{-1}$ during the first $10 \mathrm{~d}$ of incubation. After Day 10, the release of ammonium ceased as did the release of phosphate after additional $5 \mathrm{~d}$ (Fig. 3 , Table 3). Assuming that mineralisation took place as described by Redfield et al. (1963), with a $-\mathrm{O}_{2} / \mathrm{CO}_{2}$ ratio of 1 , both the rates of inorganic nitrogen ( $\mathrm{IN}=$ ammonium + nitrate) and phosphate release were low in comparison to the oxygen consumption. The $-\mathrm{O}_{2} / \mathrm{IN}$ flux ratio increased with time (Table 3 ) and continuously exceeded the values expected from the $\mathrm{C} / \mathrm{N}$ composition of the sediment (Table 2). DON comprised 46 and $58 \%$ of the total release of dissolved nitrogen (DN), before and after Day 10, respectively. 


\section{Flux rates after algal additions}

The additions of diatoms to the sediment surface of 4 cores resulted in dramatically increased net fluxes between sediment and overlying water (Fig. 3). Instances with significant differences (ANOVA, $p<0.05)$ in flux rates between cores with and without added algae are indicated in Fig. 3. Within $1 \mathrm{~d}$, the oxygen consumption rate was nearly doubled and the release of nitrate switched to a net uptake by the sediment. The plot of nitrate flux versus time, shared features with both the plot of oxygen concentration and oxygen consumption versus time. The nitrate flux was of little importance and the nitrite flux insignificant relative to ammonium release which reached a maximum of $80 \mu \mathrm{mol} \mathrm{m}^{-2} \mathrm{~h}^{-1}$ within a few days. DON release from the sediment showed a similar but smaller increase. The algal additions caused a slight uptake of phosphate by the sediment for a few days, but thereafter phosphate was also released at relatively high rates. Responses due to algal additions appeared at various times in various cores and taking these 'lags' into account, it could be shown that the algal additions resulted in significantly (ANOVA, p < 0.05) different rates of phosphate flux compared with the controls for $1 \mathrm{wk}$, both during the period of uptake ( $3 \mathrm{~d}$ ) and the period of rapid release ( $4 \mathrm{~d}$ ). Approximately $1 \mathrm{wk}$ after the algal additions, all measured constituents had reached their maximum flux rates. Subsequently the flux rates did not, with the exception of nitrate, return to the level of the controls or to that measured in the same cores prior to the addition of algae. Throughout the experiment, the net efflux of DN and of ammonium remained significantly higher than both the efflux before the algae were added and that in the controls, the same being true for DON most of the time (Fig. 3). Oxygen consumption levelled out at rates that were approximately twice as high as in the controls and also significantly higher than before the addition of algae.

As the rise and decline in nitrogen and phosphate fluxes were not synchronized, the mean flux rates were calculated before and after algal additions (Table 3, net amounts released or taken up from Days 1 to 10 and from Days 10 to 19 , respectively, divided by time). The oxygen consumption rate increased on average 1.6 times due to the algal additions and IN and phosphate release rates increased 4.5 and 3.3 times, respectively. The impact of the algae appeared even larger when compared with the controls. Both the $-\mathrm{O}_{2} / \mathrm{IN}$ molar flux ratio of 11 and the IN/PO ${ }_{4}^{3-}$ flux ratio of 14 were much lower than in the controls and the former was also lower than before the algae were added (Table 3). There was a significant correlation between the release of DON and phosphate (Fig. 4).

In order to arrive at the fraction of the algae that had

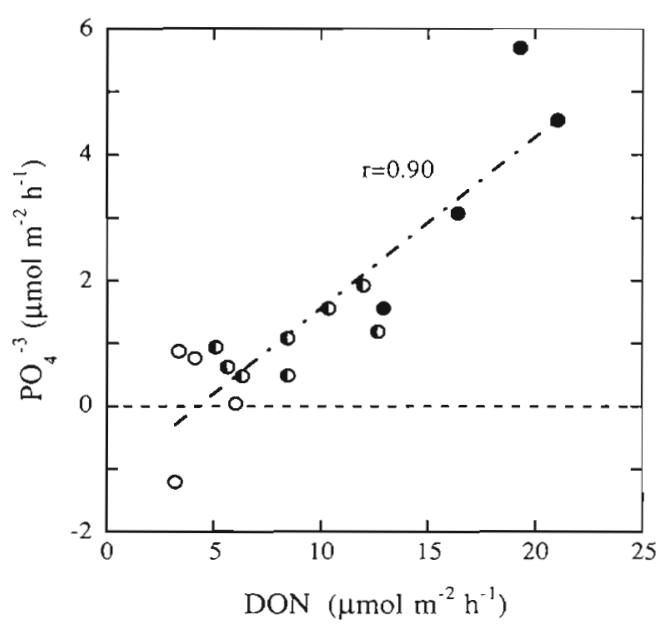

Fig. 4. Flux of phosphate versus the DON flux, mean values for individual cores: (0) Days 1 to $10 ;(\bullet)$ Days 10 to 29, algae added; (o) Day 10 to 29, controls

been recycled, the difference, manipulated cores minus controls, was calculated regarding the net amounts of nutrients and oxygen that had been released or taken up by sediment during the $19 \mathrm{~d}$ of incubation (data in Table 3 multiplied by time). This excess of IN, DON and phosphate that had been released due to the algal additions before the end of the experiment corresponded to $33 \%$ of the added algal $\mathrm{N}$ and $\mathrm{P}$ (N/P molar ratio assumed to be 16 in added algae; Redfield 1934). The excess oxygen that had been consumed could have oxidized $23 \%$ of the added algal carbon to $\mathrm{CO}_{2}$, using a $-\mathrm{O}_{2} / \mathrm{CO}_{2}$ ratio of 1 (Redfield et al. 1963).

The flux rates measured after the algal additions were also used to estimate concentration changes that might be expected in the deep water due to benthic activity after a bloom. The sediment would have removed $35 \mu \mathrm{mol} \mathrm{l^{-1 }}\left(1.1 \mathrm{ml} \mathrm{l}^{-1}\right)$ of oxygen and added $2.9 \mu \mathrm{mol} \mathrm{l}^{-1}$ of IN, $1.2 \mu \mathrm{mol} \mathrm{l^{-1 }}$ of DON and $0.23 \mu \mathrm{mol}$ $\mathrm{l}^{-1}$ of $\mathrm{PO}_{4}{ }^{3-}$ over a $19 \mathrm{~d}$ period, assuming a deep water column of $7 \mathrm{~m}$.

The ammonium release from the 2 cores that turned anoxic at the end of the experiment reached maximum values of $87 \mu \mathrm{mol} \mathrm{m} \mathrm{m}^{-2} \mathrm{~h}^{-1}$ (diatoms added) and $64 \mu \mathrm{mol}$ $\mathrm{m}^{-2} \mathrm{~h}^{-1}$ (without diatoms) The phosphate release increased more dramatically, giving $\mathrm{NH}_{4}{ }^{+} / \mathrm{PO}_{4}{ }^{3-}$ flux ratios of 1.8 (diatoms added) and less than 4.6 (without diatoms) at the time when iron sulfide appeared at the sediment surface.

\section{DISCUSSION}

\section{Fluxes without algal additions}

The sediment-water flux rates for nutrients and for oxygen consumption obtained at high oxygen condi- 
tions during this and later studies in the eastern Kattegat (Enoksson et al. 1990) were at the lower end of the ranges given for subtidal sediments by Lancelot \& Billen (1985) and by Boynton et al. (1980). Higher rates of benthic IN release were found in nearby Aarhus Bight (Jensen et al. 1990) and in the open Kattegat (Blackburn \& Henriksen 1983). The relatively low flux rates for the sediments in Laholm Bay may be related to the relatively low abundance of macro-fauna and the very low organic content (Table 2). These features may, in turn, be the result of the frequent resuspension and transportation of detritus out of the bay (Flodérus \& Håkanson 1989).

Boynton \& Kemp (1985) reported, for the spring period, a much lower release of IN from the sediment relative to oxygen consumption than what was predicted by the Redfield model (Redfield et al. 1963). Kemp et al. (1990) showed that in Chesapeake Bay this phenomenon was due to benthic nitrification and denitrification. The oxygen consumption at Stn YG (Table 3 ) indicates a net ammonium production in the order of $30 \mu \mathrm{mol} \mathrm{m} \mathrm{m}^{-2} \mathrm{~h}^{-1}$ although the non-gaseous inorganic nitrogen that was actually released was only about $10 \mu \mathrm{mol} \mathrm{m}^{-2} \mathrm{~h}^{-1}$. This was not due to a temporary accumulation of nitrogen in the sediment as both the sediment $\mathrm{C} / \mathrm{N}$ ratio (Table 2 ) and the $-\mathrm{O}_{2} / \mathrm{IN}$ flux ratio (Table 3 ) increased somewhat with time. Furthermore, the accumulation of ammonium in the sediment was not likely to be important because the low $\mathrm{K}^{+}$-exchangeable fraction of the ammonium pool indicated a low incidence of ammonium absorbtion onto particles (Blackburn \& Henriksen 1983). The fact that nitrification occurred was evident from the in situ peak of nitrate in the upper $1 \mathrm{~cm}$ and from the actual release of nitrate from the sediment (Fig. 3). The missing twothirds of IN had probably been lost through coupled nitrification and denitrification. Later estimates of 'nitrogen loss' in Laholm Bay sediments in the autumn gave slightly higher rates whereas direct measurements gave lower rates $\left(<12 \mu \mathrm{mol} \mathrm{N} \mathrm{m}^{-2} \mathrm{~h}^{-1}\right.$ ) (Enoksson et al. 1990) than those obtained in the present study.

\section{Fluxes after algal additions}

Following the addition of diatoms, the dramatic increase in the flux rates of all studied constituents was in accordance with the findings of Garber (1984a). Furthermore, Jensen et al. (1990) observed similar changes in fluxes from Aarhus Bight sediment after the settlement of the spring bloom, in accordance with the increasing ammonium and decreasing nitrate and oxygen concentrations in the bottom water. The fact that the oxygen consumption rate was promptly elevated in response to the addition of substrate (Fig. 3) was in agreement with the immediate increase in electron transport system activity of the benthic microorganisms as reported by Graf et al. (1982). Oxygen would have been depleted closer to the sediment-water interface than before treatment (Jørgensen \& Revsbech 1985, Rasmussen 1989), and the immediate shift from release to uptake of nitrate by the sediment indicates a temporary stimulation of nitrate reducers and/or inhibition of nitrifiers. During the period with the lowest oxygen concentrations (Fig. 3, Days 15 to 21), the rates of ammonium release by the sediment agreed with the ammonium production as deduced from the oxygen consumption (Redfield et al. 1963) and consequently, there was no evidence of denitrification. Even though the conditions regarding oxygen and organic substrate might have increased the potential for denitrification, the inflow of nitrate-rich water to the overlying volume and the nitrate diffusion into the sediment now set the limit for this process.

An early accumulation of reduced substances and of nitrogen in the sediment may affect the 'Redfield estimates' of nitrogen loss. Such non-steady state effects were partly overcome by making 'Redfield estimates' for an extended period (Table 3). Benthic nutrient recycling was enhanced several fold over a $3 \mathrm{wk}$ period by the addition of algae whereas denitrification might have been relatively unaffected. Estimates of 'IN loss' in Table 3 indicate a considerably decreased denitrification/mineralisation ratio as compared with the controls and the period before the algal additions. An upper conceivable denitrification rate of $120 \mu \mathrm{mol} \mathrm{m} \mathrm{m}^{-2} \mathrm{~h}^{-1}$ was obtained by assuming that the mineralised material had the same composition as the added algae $(\mathrm{C} / \mathrm{N}=6.4)$, and that the mineralisation rate was twice as high as indicated by the oxygen consumption rate (cf. Enoksson et al. 1990). Still, under such unlikely conditions, the fraction of the mineralised nitrogen that was 'lost' and probably denitrified ( $71 \%$ ) did not exceed that of the controls.

DON, which was a significant part of the released nitrogen (Table 3), may have consisted partially of auto-lysis products, at least in the cores to which diatoms had been added. Garber (1984b) argued that autolytically released dissolved organic material (DOM) was rapidly and completely mineralized and he also demonstrated that DON of benthic origin is fairly easily mineralized (Garber 1984a). DOM should therefore be taken into account as a potential nutrient source. DON made up a high and constant fraction of the pore-water nitrogen in all cores that had been overlain with oxic water throughout the experiment. In the 2 cores that turned anoxic however, much of the DON had probably disappeared from the pore water (Fig. 2), and the release of DON ceased (not shown). 
This implies that DON was regulated by the oxygen conditions or related factors. Reichardt (1986) reported that sediment proteolytic activity was reduced when oxygen availability or Eh became limiting. Further evidence was given by Hoppe et al. (1990) who noted that the peptidase activity of a natural community of aerobic heterotrophic bacteria was severely lowered by the presence of $\mathrm{H}_{2} \mathrm{~S}$. Regardless of the mechanisms, those results indicate that a substantial amount of DON could disappear during anoxic periods and this would further emphasize that a large portion of the sediment DON-pool turns over rapidly.

The benthic uptake of phosphate shortly after the algal additions may have been due to abiotic binding by the sediment (Bray et al. 1973, Krom \& Berner 1981) or to uptake by a growing microbial community. As the mean IN/ $/ \mathrm{O}_{4}{ }^{3-}$ flux ratio for the $19 \mathrm{~d}$ after algal addition was close to what would be expected from degradation of algal material (Table 3) (Redfield et al. 1963), no other process appeared to be important over this time span. This is consistant with the findings of Caraco et al. (1990) that most of the phosphorus that is mineralized in marine sediments is released into solution. The rates of phosphate and DON release (mean values for individual cores) were positively correlated (Fig. 4), which suggests that DON and phosphate had a common origin, e.g autolysis (Garber 1984b), or that phosphate was formed during mineralization of DOM in the overlying water. The latter appears to fit the period of rapid release of phosphate (Fig. 3), even though low oxygen conditions might also have increased the release of phosphate as observed by Balzer et al. (1983). This was most evident for the 2 finally anoxic cores by their very rapid release of phosphate relative to nitrogen. The FeS that was visible on the surface of these cores had probably formed when iron-bound phosphate was replaced with sulfide ions (Hallberg et al. 1976).

\section{Benthic versus land based nutrient supply}

The half-life of the algae material was estimated from the excess release of IN and DON (Table 3, controls subtracted) to be 4 wk whereas Garber (1984a) reported a half-life for experimentally added algal material of only 2 to $3 \mathrm{wk}$. According to Graf et al. (1982) and Graf et al. (1983) the spring bloom was completely degraded within 3 to $6 \mathrm{wk}$. Therefore, it is obvious that sediment-water fluxes depend very much on recent sedimentation. On the other hand, the relevance of these results for Laholm Bay depends largely on if the added amounts of algae in this experiment were realistic. This appears to be the case because (1)
$3 \mathrm{~g}$ of non-resuspended organic carbon settled during 2 wk of the spring bloom period at Stn YG (Rydberg et al. 1990) and this corresponded to half of the added algal carbon; (2) amounts equivalent to the added carbon would settle at the bottom of the Kiel Bight during a few weeks in the autumn (Noji et al. 1986); and (3) the added algal nitrogen corresponded to $30 \%$ of the 'new' nitrogen supply to the upper water layers of Laholm Bay during the productive season (Granéli et al. 1986, supply divided by bay area of $450 \mathrm{~km}^{2}$ ), thus being comparable to the sedimenting part of the autumn bloom of which the total comprized $30 \%$ of the yearly production (Rydberg et al. 1990).

Even though low, the benthic nitrogen release that is typical for the eastern Kattegat (Enoksson et al. 1990) is relatively important compared with other sources. The release of nitrogen (IN + DON) measured before the additions of algae would, for example, correspond to as much as $70 \%$ of the land-based supply of IN in the autumn, and the release of phosphaie would be 3 times as large as the land-based supply (Graneli et al. 1986). The latter is in accordance with the finding that the euphotic zone receives most of the phosphate from the deep water during the productive season (Rydberg et al. 1990).

Extrapolating these results to the size of Laholm Bay, although not warranted for budget calculations, may elucidate the great influence of benthic fluxes in this area. The excess release subsequent to the settlement of algae, would comprise 1.5 times the nitrogen (2 times including DON) and 11 times the phosphate that was introduced per unit time and area via fresh water runoff in the autumn. As various pore-water constituents accumulated in all cores during incubation (Table 2, Fig. 4), the stirring had probably been somewhat too slow and the anaerobic degradation relatively more important than in situ. This might have exaggerated the effects of algal addition compared to in situ conditions. However, more important was probably that the oxygen concentrations were lowered temporarily as the added algae were degraded (Fig. 3), analogous to the lowering of oxygen concentrations in the deep water after the settlement of the autumn bloom. Only concentration changes in the deep water can be used as reliable references to flux measurements such as this, as no confinement of the water above the sediment is required. The close resemblance with the in situ results from the Aarhus Bight (Jensen et al. 1990) indicates that the incubation conditions used in this experiment mimicked the in situ conditions well enough to give qualitatively reliable results. In conclusion, the results strongly suggest that the sediment of this shallow, stratified bay will not act as an efficient nitrogen or phosphorus sink upon the deposition of large algal blooms. 
Acknowledgements. Anna-Kerstin Thell is acknowledged for excellent technical assistance and Peter Möler for determining animal species. I am grateful to Staffan Kjelleberg, Ulf Rönner and Fred Sörensson for valuable discussions and to Patrucia Conway and Maureen Jehler for correcting the langrage. This work was supported by grants from the Swedish Environmental Protection Agency.

\section{LITERATURE CITED}

Armstrong, F. A. J., Stern, C. R., Strickland, J. D. H. (1967). The measurement of upwelling and subsequent biological processes by means of the Technicon AutoAnalyzer and associated equipment. Deep Sea Res. 14: 381-389

Balzer, W. (1984). Organic matter degradation and biogenic element cycling in a nearshore sediment (Kiel Bight) Limnol. Oceanogr. 29: 1231-1246

Balzer, W., Grasshoff, K., Dieckmann, P., Haardt, H., Petersohn, U. (1983). Redox-turnover at the sediment/water interface studied in a large bell jar system. Oceanol. Acta 6: $337-344$

Blackburn, T H., Henriksen, K. (1983). Nitrogen cycling in different types of sediments from Danish waters. Limnol Oceanogr. 28: 477-493

Boynton, W. R., Kemp, W. M. (1985). Nutrient regeneration and oxygen consumption by sediments along an estuarine salinity gradient. Mar. Ecol. Prog. Ser. 23: 45-55

Boynton, W. R., Kemp, W. M., Osborne, C. G. (1980). Nutrient fluxes across the sediment-water interface in the turbid zone of a coastal plain estuary. In: Kennedy, V. S. (ed.) Estuarine perspectives. Academic Press, New York, p. $93-109$

Bray, J. T., Bricker, O. P., Troup, B. N. (1973). Phosphate in interstitial waters of anoxic sediments: oxidation effects during sampling procedure. Science 180: 1362-1364

Caraco, N., Cole, J., Likens, G. E. (1990). A comparison of phosphorus immobilization in sediments of freshwater and coastal marine systems. Biogeochemistry 9: 277-290

Dugdale, R. C., Goering, J. J. (1967). Uptake of new and regenerated forms of nitrogen in primary productivity. Limnol. Oceanogr 12: 196-206

Enoksson, V., Samuelsson, M.-O. (1987). Nitrification and dissimilatory ammonium production and their effects on nitrogen flux over the sediment-water interface in bioturbated coastal sediments. Mar. Ecol. Prog. Ser. 36: 181-189

Enoksson, V., Sörensson, F., Granéli, W. (1990). Nitrogen transformations in the Kattegat. Ambio 19: 159-166

Eppley, R. W., Renger, E. H., Betzer, P. R. (1983). The residence time of particulate carbon in the surface layer of the ocean. Deep Sea Res. 30: 311-323

Flodérus, S., Håkanson, L. (1989). Resuspension, ephemeral mud blankets and nitrogen cycling in Laholmsbukten south east Kattegat. Hydrobiologia 176/177: 61-75

Garber, J. H. (1984a). ${ }^{15} \mathrm{~N}$ tracer study of the short-term fate of particulate organic nitrogen at the surface of coastal marine sediments. Mar. Ecol. Prog. Ser. 16: 89-104

Garber, J. H. (1984b). Laboratory study of nitrogen and phosphorus remineralization during the decomposition of coastal plankton and seston. Estuar. coast. Shelf Sci. 18: $685-702$

Graf, G., Bengtsson, W., Diesner, U., Schulz, R., Theede, H. (1982). Benthic response to sedimentation of a spring phy- toplankton bloom: process and budget. Mar. Biol. 67 $201-208$

Graf, G., Schulz, R., Peinert, R., Meyer-Reil, L.-A. (1983) Benthic response to sedimentation events during autumn to spring at a shallow-water station in the Western Kiel Bight. Mar. Biol. 77: 235-246

Granéli, E., Granéli, W., Rydberg, L. (1986). Nutrient limitation at the ecosystem and phytoplankton community level in the Laholm Bay, South-East Kattegat. Ophelia 26: $181-194$

Hallberg, R. O., Bågander, L. E., Engvall, A.-G. (1976). Dynamics of phosphorus, sulfur and nitrogen at the sediment-water interface. In: Nriagu, J.O. (ed.) Environmental biogeochemistry, Vol. 1. Ann Arbor Science, Ann Arbor, MI, p. 295-308

Henriksen, K., Kemp, W. M. (1988). Nitrification in estuarine and coastal marine sediments. In: Blackburn, $\mathrm{T} H$., Sørensen, J. (eds.) Nitrogen cycling in coastal marine environments. Wiley, New York, p. 207-249

Hoppe, H. G., Gocke, K., Kuparinen, J. (1990). Effects of $\mathrm{H}_{2} \mathrm{~S}$ on heterotrophic substrate uptake, extracellular enzyme activity and growth of brackish water bacteria. Mar. Ecol. Prog. Ser. 64: 157-167

Jenkins, M. C., Kemp, W. M. (1984). The coupling of nitrification and denitrification in two estuarine sediments. Limnol. Oceanogr. 29: pp. 609-619

Jensen, M. H., Andersen, T. K., Serensen, J. (1988). Denitrification in coastal bay sediment: regional and seasonal variation in Aarhus Bight. Denmark. Mar. Ecol. Prog. Ser 48: $155-162$

Jensen, M. H., Lomstein, E., Sørensen, J. (1990). Benthic $\mathrm{NH}_{4}{ }^{+}$ and $\mathrm{NO}_{3}{ }^{-}$flux following sedimentation of a spring phytoplankton bloom in Aarhus Bight, Denmark. Mar. Ecol. Prog. Ser. 61:87-96

Jørgensen, B. B., Revsbech, N. P. (1985). Diffusive boundary layers and the oxygen uptake of sediments and detritus. Limnol. Oceanogr. 30: 111-122

Kelly, J. R., Nixon, S. W. (1984). Experimental studies of the effect of organic deposition on the metabolism of a coastal marine bottom community. Mar. Ecol. Prog. Ser. 17: $157-169$

Kemp, W. M., Sampou, P., Caffrey, J., Mayer, M., Henriksen, K., Boynton, W. R. (1990). Ammonium recycling versus denitrification in Chesapeake Bay sediments. Limnol Oceanogr. 35: 1545-1563

Kieskamp, W. M., Lohse, L., Epping, E., Helder, W. (1991). Seasonal variation in denitrification rates and nitrous oxide fluxes in intertidal sediments of the western Wadden Sea. Mar. Ecol. Prog. Ser. 72: 145-151

Koike, I., Sørensen, J. (1988). Nitrate reduction and denitrification in marine sediments. In: Blackburn, $\mathrm{T} H$. Sørensen, J. (eds.) Nitrogen cycling in coastal marine environments. Wiley, New York, p. 251-273

Koroleff, F. (1976). Determination of ammonia. In: Grasshoff, K. (ed.) Methods of seawater analysis. Verlag Chemie, New York, p. 126-133

Krom, M. D., Berner, R. A. (1981). The diagenesis of phosphorus in a nearshore marine sediment. Geochim. Cosmochim. Acta 45: 207-216

Lancelot, C., Billen, G. (1985). Carbon-nitrogen relationships in nutrient metabolism of coastal marine ecosystems. Adv. aquat. Microbiol. 3: 263-321

Meybeck, M. (1982). Carbon, nitrogen, and phosphorus transport by world rivers. Am. J. Sci. 282: 401-450

Murphy, J., Riley, J. P. (1962). A modified single solution method for the determination of phosphate in natural waters. Anal. Chim. Acta 27:31-36 
Nixon, S. W. (1981). Remineralization and nutrient cycling in coastal marine ecosystems. In: Neilson, B.J., Cronin, L. E. (eds.) Estuaries and nutrients. Humana Press, Clifton, NJ, p. $111-138$

Noji, T., Passow, U., Smetacek, V. (1986). Interaction between pelagial and benthal during autumn in Kiel Bight. I. Development and sedimentation of phytoplankton blooms. Ophelia 26: 333-349

Rasmussen, H. (1989). Oxygen uptake of sediments with special reference to the seasonal variation in Aarhus Bight. M.Sc. thesis, Univ. of Aarhus

Redfield, A. C. (1934). On the proportions of organic derivatives in seawater and their relation to the composition of plankton. In: Daniel, R. J. (ed.) James Johnstone memorial volume. University Press, Liverpool, p. 176-192

Redfield, A. C., Ketchum, B., Richards, F. A. (1963). The influence of organisms on the composition of seawater. In: Hill, M. N. (ed.) The sea. Interscience Publishers, New York, p. $26-77$

Reichardt, W. (1986). Enzymatic potential for decomposition of detrital biopolymers in sediments from Kiel Bay. Ophelia 26: 369-384

Rosenberg, R., Elmgren, R., Fleischer, S., Jonsson, P., Persson, G., Dahlin, H. (1990). Marine eutrophication case studies in Sweden. Ambio 19: 102-108

Rydberg, L., Edler, L., Flodérus, S., Granéli, W. (1990). Interaction between supply of nutrients, primary production.

This article was submitted to the editor sedimentation and oxygen consumption in SE Kattegat Ambio 19: 134-141

Seitzinger, S. P. (1988). Denitrification in freshwater and coastal marine ecosystems: ecological and geochemical significance. Limnol. Oceanogr. 33: 702-724

Seitzinger, S. P., Nixon, S. W., Pilson, M. E. Q. (1984). Denitrification and nitrous oxide production in a coastal marine ecosystem. Limnol. Oceanogr. 29: 73-83

Shaffer, G., Rönner, U. (1984). Denitrification in the Baltic proper deep water. Deep Sea Res. 31: 197-220

Sundbäck, K., Enoksson, V., Granéli, W., Pettersson, K (1991). Influence of sublittoral microphytobenthos on the oxygen and nutrient flux between sediment and water: a laboratory continuous-flow study. Mar. Ecol. Prog. Ser. 74 $263-279$

Svanson, A. (1975). Physical and chemical oceanography of the Skagerrak and the Kattegat. I. Open sea conditions. Fishery Bd Sweden, Inst. Mar. Res. Report No. 1, Lysekil

Valderrama, J. C. (1981). The simulianeous analysis of total nitrogen and total phosphorus in natural waters. Mar. Chem. 10: $109-122$

Wassmann, P. (1990). Relationship between primary and export production in the bored coastal zone of the North Atlantic. Limnol Oceanogr. 35: 464-471

Wulff, F., Stigebrandt, A., Rahm, L. (1990). Nutrient dynamics in the Baltic Sea. Ambio 19: 126-133

Manuscript first received: October 16, 1991

Revised version accepted: December 15, 1992 